\title{
Population Trends in Finland since $1950^{*}$
}

\author{
by ALTTI MAJAVA
}

Two features stand out in the demographic developments in Finland since the Second World War: the gradual decrease in population growth, and the widening regional differences in population change. As a consequence of the substantial increase in the birth rate, the annual population increase reached its peak of 54000 persons, or 14 per thousand, in 1946. In the five-year period, $1951-1955$, the annual growth averaged 47000 persons, or 11 per thousand, whereas it was less than 25000 persons, or only 5 per thousand, per year in 19661968. The main cause for the retardation of population growth was the considerable decline in the birth rate (from 22.1 per 1000 in $1951-1955$ to 16.7 in 1966), together with some increase in net emigration. At the same time, there widened the gap between Uusimaa, the economic region with the highest growth rates ( 22 to 25 per 1000 a year), and the other regions, particularly those in which population diminished. In $1951-1955$, the population declined slightly in one region (Ahvenanmaa), whereas five of the 16 economic regions experienced a reduction in population in 1966. While the population declined in an increasing number of rural communes, the four communes comprising the Greater Helsinki area had a

* Based on a survey by the author, Väestönmuutokset talousalueittain ja kunnittain vuosina 1951-66 (with English summary: Population changes in Finland by economic regions and communes in 1951-1966), Publications of the National Planning Office, Series A: 21, Helsinki, 1968, pp. 174. growth rate of three per cent a year throughout the period under review. Thus, in 1966, the population growth in Greater Helsinki corresponded to two-thirds of the increase in the country's population.

According to the censuses, the population of Finland numbered 4029800 persons in 1950, and 4446200 persons in 1960 . The vital statistics yield a population of 4625700 persons for 1965 , but discounting the unrecorded net emigration in 19611965 , the actual population may be estimated at 4583000 persons only. The population growth slowed down considerably in the 15-year period under review: the recorded rates per 1000 per year declined from 11.4 in $1951-1955$ to 9.4 in $1956-1960$ and to 7.9 in 19611965. If the unrecorded net emigration is deducted, however, the actual growth rates may have been $11.1,8.7$ and 6.0 , respectively. In 1966, the recorded rate was 5.4, while the actual increase was about $5.0-5.2$ per 1000 population.

The population of Finland increased by 553000 persons, or 13.7 per cent, from 1950 to 1965 . As Figure 1 indicates, the growth rate exceeded the national average in the economic region of Uusimaa in the South (increase around 40 per cent), and in the three northernmost regions, Lappi, Pohjois-Pohjanmaa (about 30 per cent in both) and Kainuu (21 per cent). In the Swedish-speaking island region of Ahvenanmaa, the population declined by about 5 per cent, while in the other southern regions (except Uusimaa) the growth (6-13 per cent) fell somewhat short of the national average. In the central parts of the country, the 1965 
population differed from the 1950 population by less than 5 per cent. The urban population increased by slightly more than 40 per cent; the most rapid growth (over 50 per cent) was recorded in the northern and eastern regions. The population of the rural communes remained almost unchanged (diminution by 25000 persons, or one per cent). Nevertheless, the rural population increased in the four fast-growing regions mentioned above, and in the Keski-Suomi region, while it declined in the rest of the country - in Ahvenanmaa by as much as 20 per cent. The population increase in the urban communes was rather steady over the entire 15-year period in all the economic regions, whereas the developments in the rural communes varied greatly both in time and in regions.

Table 1 presents the statistics of population change for the three five-year periods and the year 1966. While the preceding discussion of Figure 1 was based upon the estimated actual population changes, Table 1 is a reproduction of official vital statistics which considerably underrate emigration since 1954. Thus, data for the 1960's and the regions of Ahvenanmaa, Etelä-Pohjanmaa, Keski-Pohjanmaa and Vaasa Coast, in particular, do not reflect reality quite correctly. Nevertheless, this shortcoming does not materially affect the main trends.

In the Uusimaa region, the growth rate was remarkably steady in each five-year period, somewhat exceeding 20 per 1000 population per annum. As population growth slackened in most other regions, the rise was increasingly concentrated in Uusimaa, i.e. Greater Helsinki. In the 1950 's, the growth rate of Uusimaa was almost equalled - and in the early years of the decade even exceeded - in the three northernmost regions. Even in 1966, the population increase exceeded the national average in Pohjois-Pohjanmaa, but in Kainuu and Lappi it had come to a standstill by 1965 . The population ceased to grow also in Keski-Suomi, Satakunta and Kaakkois-Suomi by the mid-1960's; in Etelä-Pohjanmaa it was stationary over the 15-year period. In the three eastern regions (Pohjois-Karjala, Pohjois-Savo, Etelä-Savo), the population started decreasing in the late 1950's, and in Ahvenanmaa the real trend was downward in each period. In Keski-Pohjanmaa, the population declined in 1956-1960, but slowly resumed growth in the 1960 's. The trends for the rural population generally followed a parallel course; nevertheless, the population increase slackened, and or the decline accelerated more markedly in rural communes than in the economic regions as a whole. In 1966 the rural population increased in Uusimaa only.

The number of communes in which population increased diminished considerably in the period under review, although in the 1960's it seems to have stabilised at around 160 . With the exception of a few small towns, in each period, the population grew in all the 70 urban communes, while the number of rural communes in which the population increased was halved and amounted to aroung onehundred in the 1960 's. Consequently, the population decreased in about 220 rural communes in 1951-1955, and in about 380 of the 476 rural communes in the

\section{ABBREVATIONS FOR THE ECONOMIC REGIONS}

in figures and cartograms

$$
\begin{aligned}
& \mathrm{U}=\text { Uusimaa } \\
& \mathrm{A}=\text { Ahvenanmaa }^{1} \\
& \mathrm{VS}=\text { Varsinais-Suomi } \\
& \mathrm{S}=\text { Satakunta } \\
& \mathrm{T}=\text { Tammermaa } \\
& \mathrm{EH}=\text { Etelä-Häme } \\
& \mathrm{KaS}=\text { Kaakkois-Suomi } \\
& \mathrm{ES}=\text { Etelä-Savo } \\
& \mathrm{PK}=\text { Pohjois-Karjala } \\
& \mathrm{PS}=\text { Pohjois-Savo } \\
& \mathrm{Kes}=\text { Keski-Suomi } \\
& \mathrm{EP}=\text { Etelä-Pohjanmaa } \\
& \mathrm{KP}=\text { Keski-Pohjanmaa } \\
& \mathrm{K}=\text { Kainuu } \\
& \mathrm{PP}=\text { Pohjois-Pohjanmaa } \\
& \mathrm{L}=\text { Lappi } \\
& \mathrm{VR}=\text { Vaasan rannikko }{ }^{2}
\end{aligned}
$$

1 Swedish-speaking autonomous province.

2 Comprising of Swedish-speaking or bilingual communes in Southern and Central Ostrobothnia; not an economic region as the 16 economic regions proper. 

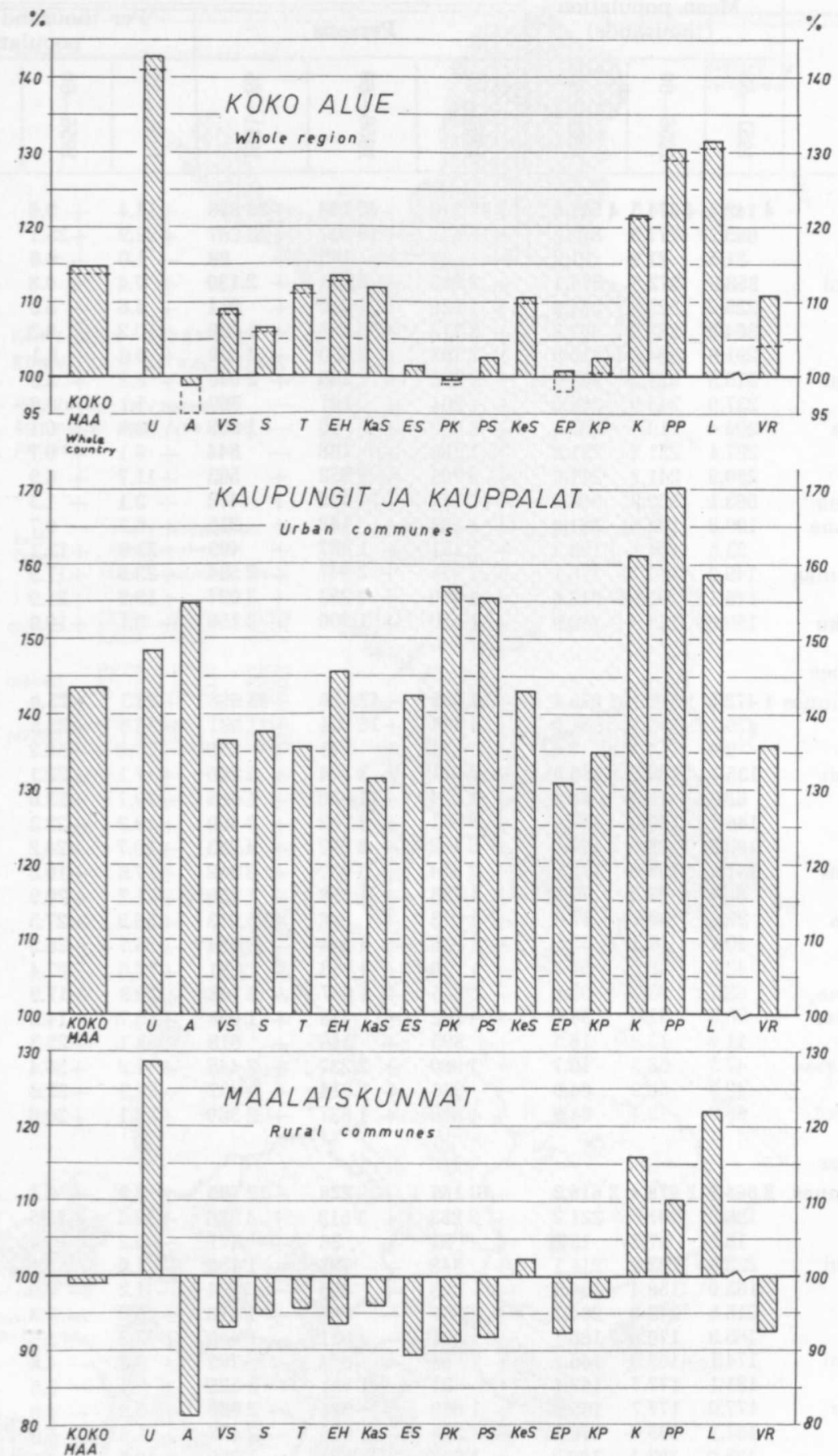

Figure 1. Population change by economic regions and urban/rural residence from 1950 to 1965, per cent - Column denotes the recorded, and the broken line the estimated actual population in 1965 as percentage of the 1950 population. 
Table 1. Mean population and population change by economic regions and urban/ rural residence in each five-year period, 1951-1965, and in 1966

\begin{tabular}{|c|c|c|c|c|c|c|c|c|c|c|}
\hline \multirow[b]{3}{*}{ Region } & \multirow{2}{*}{\multicolumn{3}{|c|}{$\begin{array}{l}\text { Mean population } \\
\text { (thousands) }\end{array}$}} & \multicolumn{7}{|c|}{ Population change (annual averages) } \\
\hline & & & & \multicolumn{3}{|c|}{ Persons } & \multicolumn{4}{|c|}{$\begin{array}{l}\text { Per thousand of mean } \\
\text { population }\end{array}$} \\
\hline & & $\begin{array}{l}8 \\
0 \\
\text { ํㅗ }\end{array}$ & $\underset{-10}{10}$ & $\frac{10}{20}$ & $\begin{array}{l}0 \\
0 \\
0 \\
\stackrel{1}{\circ}\end{array}$ & क्ष & $\frac{12}{\sqrt{2}}$ & $\begin{array}{l}0 \\
0 \\
\stackrel{1}{\circ}\end{array}$ & $\frac{1}{\mathscr{6}}$ & 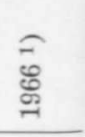 \\
\hline Whole cou & 4142.4 & 4374.5 & 4541. & +47219 & +42198 & +35898 & +11.4 & +9.6 & +7.9 & $+\mathbf{5 . 4}$ \\
\hline Uusimaa & 685.1 & 777.5 & 872.2 & 677 & +19537 & +22267 & +22.9 & +25.1 & +25.5 & +22.5 \\
\hline Ahvenanmaa & 21.5 & 21.9 & 21.2 & 22 & $+\quad 145$ & 88 & -1.0 & +6.6 & +4.1 & +6.2 \\
\hline Varsinais-Suomi & 358.9 & 372.5 & 379.1 & +2.659 & +2.531 & +2.130 & +7.4 & +6.8 & +5.6 & +4.1 \\
\hline Satakunta & 225.2 & 229.6 & 234.9 & +1029 & +1225 & 911 & +4.6 & +5.3 & +3.9 & +1.1 \\
\hline Tammermaa & 364.2 & 382.2 & 392.2 & +3712 & +3156 & +1989 & +10.2 & +8.3 & +5.1 & +3.9 \\
\hline Etelä-Häme & 291.6 & 304.8 & 315.9 & +2792 & +2460 & +2829 & +9.6 & +8.1 & +9.0 & +6.5 \\
\hline Kaakkois-Suomi & 315.5 & 327.6 & 342.0 & +2572 & +2243 & +2046 & +8.2 & +6.8 & +6.0 & +0.8 \\
\hline Etelä-Savo & 237.0 & 240.0 & 239.0 & +1204 & $+\quad 147$ & $-\quad 769$ & +5.1 & +0.6 & -3.2 & -6.3 \\
\hline Pohjois-Karjala & 204.4 & 210.0 & 202.4 & +2052 & 15 & -1968 & +10.0 & +0.1 & -9.7 & -8.2 \\
\hline Pohjois-Savo & 227.4 & 231.3 & 231.4 & +1386 & $+\quad 168$ & -844 & +6.1 & +0.7 & -3.6 & -4.4 \\
\hline Keski-Suomi & 230.9 & 241.1 & 247.6 & +2701 & +1652 & 563 & +11.7 & +6.9 & +2.3 & +0.1 \\
\hline Etelä-Pohjanmaa & 363.1 & 369.2 & 363.7 & +1117 & $+\quad 465$ & 472 & +3.1 & +1.3 & +1.3 & -1.1 \\
\hline Keski-Pohjanmaa & 199.8 & 202.6 & 201.9 & +1134 & -142 & 215 & +5.7 & -0.7 & +1.1 & +0.5 \\
\hline Kainuu & 93.5 & 104.1 & 108.2 & +2151 & +1367 & 409 & +23.0 & +13.1 & +3.8 & -1.7 \\
\hline Pohjois-Pohjanmaa & 149.2 & 164.7 & 176.1 & +3575 & +2947 & +2534 & +23.9 & +17.9 & +14.4 & +10.3 \\
\hline Lappi & 175.1 & 195.5 & 213.6 & +3480 & +4283 & +3027 & +19.9 & +21.9 & +14.2 & +3.3 \\
\hline Vaasan rannikko & 159.8 & 169.9 & 169.9 & +1450 & +1706 & +2156 & +9.1 & +10.0 & +12.7 & +4.7 \\
\hline
\end{tabular}

Urban communes

All urban communes 1473.51696 .11925 .4

Uusimaa

Ahvenanmaa

Varsinais-Suomi

Satakunta

Tammermaa

Etelä-Häme

Kaakkois-Suomi

Etelä-Savo

Pohjois-Karjala

Pohjois-Savo

Keski-Suomi

Etelä-Pohjanmaa

Keski-Pohjanmaa

Kainuu

Pohjois-Pohjanmaa

Lappi

Vaasan rannikko $\begin{array}{lll}3.4 & 4.1 & 7.4\end{array}$

$\begin{array}{lll}135.1 & 150.2 & 168.0\end{array}$

$\begin{array}{rrr}62.2 & 71.3 & 80.4\end{array}$

$\begin{array}{lll}148.7 & 169.0 & 187.6\end{array}$

$\begin{array}{lll}105.8 & 128.0 & 147.8\end{array}$

$\begin{array}{lll}141.5 & 158.6 & 175.8\end{array}$

$\begin{array}{rrr}55.9 & 62.2 & 71.9\end{array}$

$\begin{array}{lll}27.4 & 32.2 & 37.0\end{array}$

$\begin{array}{lll}40.2 & 46.3 & 55.1\end{array}$

$42.9 \quad 48.0 \quad 57.4$

83.7

28.5

11.9

47.3

42.0

69.7

\section{$93.2 \quad 99.9$}

$31.0 \quad 34.0$

$13.8 \quad 16.5$

$53.9 \quad 64.9$

79.4 $\begin{array}{ll}58.3 & 70.7\end{array}$ $\begin{array}{llr}479.1 & 576.1 & 651.0\end{array}$

$$
\begin{array}{rr}
+ & 34054 \\
+ & 13444 \\
+ & 71 \\
+ & 2311 \\
+ & 1224 \\
+ & 2851 \\
+ & 2192 \\
+ & 2484 \\
+ & 1183 \\
+ & 1013 \\
+ & 1036 \\
+ & 756 \\
+ & 1615 \\
+ & 562 \\
+ & 395 \\
+ & 1980 \\
+ & 936
\end{array}
$$

$+1680$

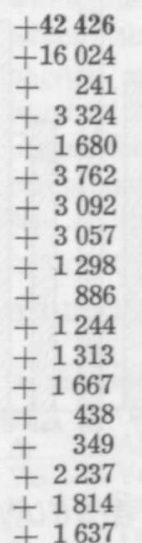

+42426
+16024
$+\quad 241$
+3324
+1680
+3762
+3092
+3057
+1298
$+\quad 886$
+1244
+1313
+1667
$+\quad 438$
$+\quad 349$
+2237
+1814
+1637

$$
\begin{aligned}
& +23.1 \\
& +26.8 \\
& +20.6 \\
& +17.1 \\
& +19.7 \\
& +19.2 \\
& +20.7 \\
& +17.6 \\
& +21.2 \\
& +36.9 \\
& +25.7 \\
& +17.6 \\
& +19.3 \\
& +19.7 \\
& +33.1 \\
& +41.9 \\
& +22.3 \\
& +24.1
\end{aligned}
$$

+25.0
+28.5

$+58.2$

$+22.1$

$+23.6$

\begin{tabular}{|c|c|c|}
\hline 188.0 & 201.5 & \\
\hline 18.0 & 17.8 & 13.8 \\
\hline 223.8 & 222.2 & 211.1 \\
\hline 163.0 & 158.4 & 154.5 \\
\hline 215.5 & 213.2 & 204.7 \\
\hline 185.9 & 176.8 & 168.1 \\
\hline 174.1 & 169.0 & 166.2 \\
\hline 181.1 & 177.7 & 167.1 \\
\hline 177.0 & 177.7 & 165.5 \\
\hline 187.2 & 185.0 & 176.3 \\
\hline 188.0 & 193.1 & 190.2 \\
\hline 279.5 & 276.0 & 263.8 \\
\hline 171.3 & 171.6 & 167.9 \\
\hline 81 & 90.3 & 91.7 \\
\hline 101.9 & 106.4 & 105.4 \\
\hline 133.1 & 141.6 & 148.7 \\
\hline
\end{tabular}

$+22.3$

$+24.2$

$+19.3$

$+20.9$

$+27.5$

$+26.9$

$+27.4$

$+17.9$

$+14.2$

$+25.3$

$+38.4$

$+33.6$

$+20.6$

$$
\begin{array}{ll}
+25.3 & +20.1 \\
+27.5 & +24.8 \\
+35.2 & +23.0 \\
+23.0 & +16.3 \\
+21.0 & +14.9 \\
+18.7 & +20.0 \\
+29.0 & +20.7 \\
+16.2 & +9.6 \\
+24.4 & +14.4 \\
+24.7 & +23.6 \\
+30.0 & +26.6 \\
+31.7 & +20.2 \\
+21.5 & +14.3 \\
+32.3 & +26.1 \\
+37.4 & +18.2 \\
+34.6 & +25.3 \\
+29.1 & +14.8 \\
+27.2 & +16.0
\end{array}
$$

Rural communes

All rural communes 2668.92678 .42616 .2

Uusimaa

Ahvenanmaa

Varsinais-Suomi

Satakunta

Tammermaa

Etelä-Häme

Kaakkois-Suomi

Etelä-Savo

Pohjois-Karjala

Pohjois-Savo

Keski-Suomi

Etelä-Pohjanmaa

Keski-Pohjanmaa

Kainuu

Pohjois-Pohjanmaa

Lappi

Vaasan rannikko
$+13165$

$+2233$

-93
$-\quad 348$

348
$+\quad 196$

$196-455$

$+861-606$

$+601-631$

$+88-814$
$+\quad 21$

+ 21151
+

$+1039$

$+\quad 350$
$+\quad 1395$

$+1945$

+
$-\quad 499$

572
$+\quad 50$

$+1756$

$+1595$

$+2544$

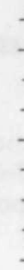

$-1076$

338
$+\quad 1203$

$-1203$

- 580

$+1019$

710
$+\quad 109$

$$
\begin{array}{r}
-12799 \\
+\quad 4336 \\
-\quad 171 \\
-1730 \\
-\quad 774 \\
-1510 \\
-1455 \\
-\quad 796 \\
-2525 \\
-2880 \\
-2498 \\
-1259 \\
-1675 \\
-\quad 883 \\
-\quad 209 \\
+\quad 89
\end{array}
$$

$+4.9$

$-0.1$

$-4.9$

$-6.5$

$+12.5$

$+15.5$

$+19.6$

$+15.5$

$-5.2$

$-5.4$

$-3.6$

$-12.4$

$-8.2$

$-3.9$

$-1.2$

$-2.9$

$-5.0$

$+4.0$

$+3.2$

$-2.8$

$-3.6$

$-7.4$

$-8.7$

$-6.4$

$-6.6$

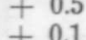

$+5.9$

$-4.8$

$-6.5$

$-4.9$

$-4.8$

$-12.4$

$+1.9$

$+10.3$

$-5.8$

$-15.1$

$-1.8$

$+1.8$

$-4.4$

$-3.4$

$+21.5$

$+11.3$

$+6.7$

$+15.6$

$+17.4$

$-14.2$

$-7.4$

$-9.2$

$-16.3$

$-16.3$

$-15.4$

1) Preliminary data. 


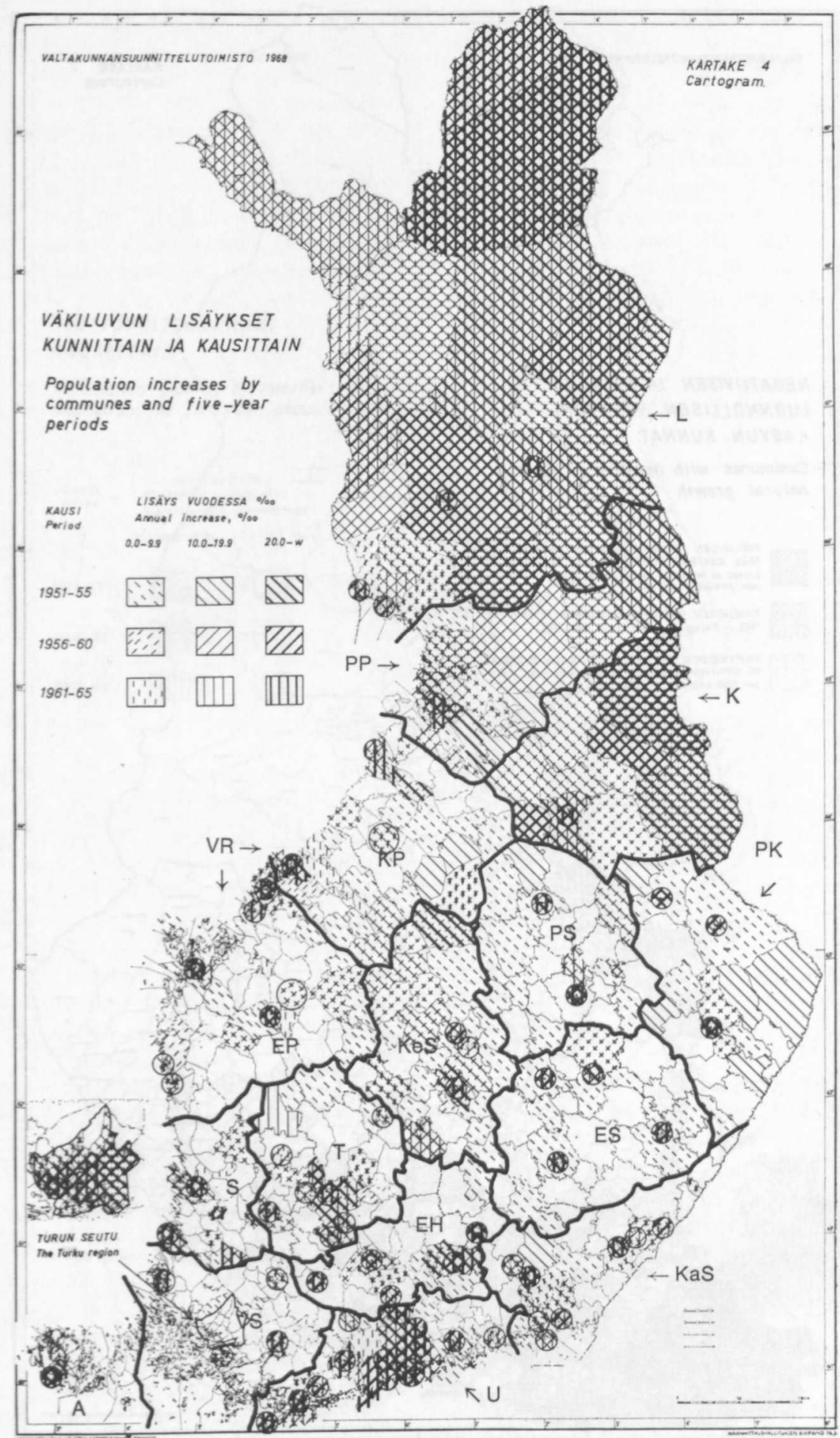

Cartogram 1. 


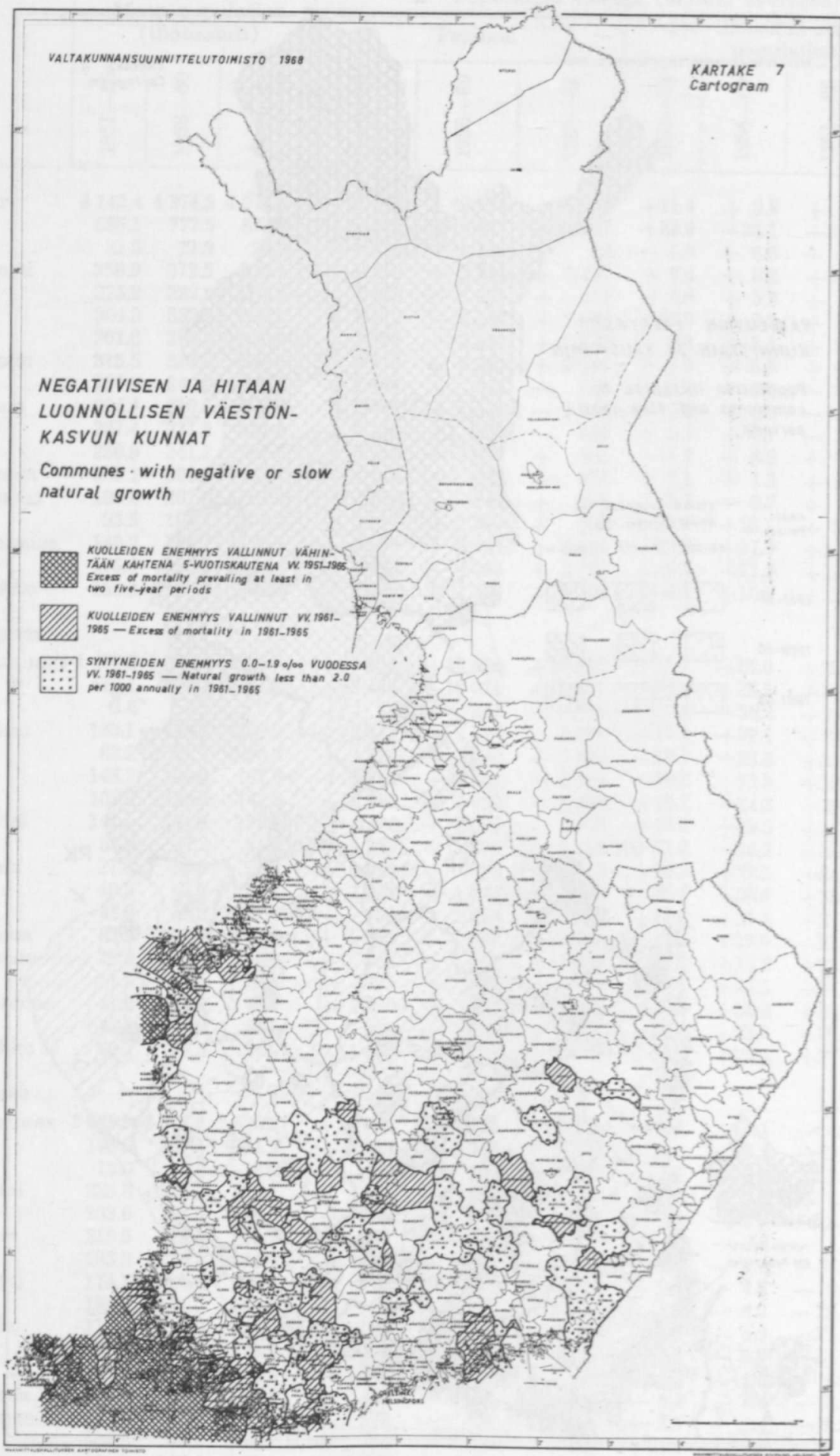

Cartogram 2. 


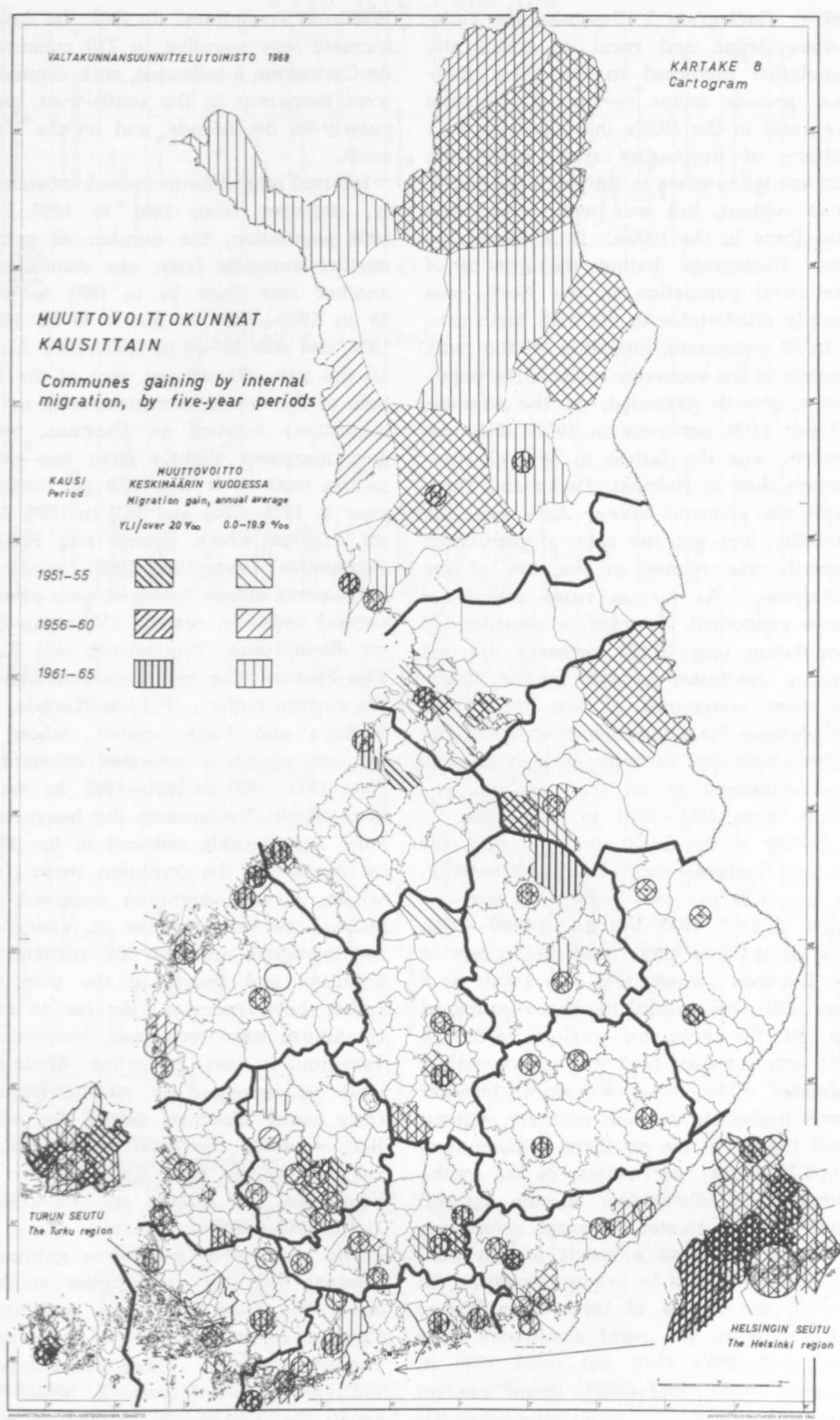

Cartogram 3. 
1960's. Cartogram 1 illustrates the communes, urban and rural, in which the population increased in the three fiveyear preiods under review. It suggests that, still in the 1950's the transition to a pattern of decreasing rural population had not taken place in the three northernmost regions, but was well under way also there in the 1960 's. It is discernible from Cartogram 3 that the growth of the rural population in the North was mainly attributable to the high birth rate.

In 58 communes, including all the main centres of the economic regions, the population growth exceeded, on the average, 20 per 1000 per year in $1951-1965$; the growth was the fastest in several communes close to Helsinki, Turku and Tampere, the principal cities. As a rule, the stability, but not the rate, of population growth was related to the size of the commune. As far as rural communes were concerned, however, a considerable population (e.g. 20000 persons) did not ensure continued growth in the 1960's; in most communes of less than 6000 inhabitants the population diminished. The inter-communal variation in growth rates was enhanced in all the economic regions from 1951-1955 to 1961-1965.

Owing to the declining birth rate, the natural increase contracted substantially: it was 12.6 per 1000 population per annum in $1951-1955$, but 8.5 in $1961-1965$, and only 7.3 in 1966 . With the exception of Uusimaa (whose rate was stable at 8 per 1000), the natural increase diminished in all the economic regions, although the order of their rank was not materially affected. The rates of natural increase were highest in the four northern regions, and lowest in the southern regions (except Uusimaa), particularly in the southwest. The diminution in the natural growth was greater in rural communes - partly also as a result of net outmigration - that in urban communes, in which the excess of births was higher than that in the rural communes after the mid-1950's (but not until 1966 in Lappi) - In 1951-1955, there was an excess of deaths in seven communes, in 1956-1960 in 16 communes, and in 1961-
1965 in 70 communes. In 1966 , the natural increase was negative in 118 communes. As Cartogram 2 indicated, such communes were numerous in the south-west, particularly in the islands, and on the Vaasa coast.

Internal migration increased substantially, stepwise, from 1951 to 1966. Per 1000 population, the number of persons moving annually from one commune to another rose from 34 in 1951 to about 38 in $1952-1954$, to about 40 in 19551959 , and was $45-50$ in 1960-1966. Almost all the gain (91-93 per cent of the total gain of the economic regions with net inmigration) accrued to Uusimaa, whose gain increased slightly from one period to the next - it was 15.9 per 1000 per year in 1951-1955 and 18.0 in 1966. Another region which gained was PohjoisPohjanmaa (excepting 1966), while the movements almost balanced each other in several southern regions (Varsinais-Suomi, Etelä-Häme, Tammermaa and Kaakkois-Suomi). The losses were heaviest in the eastern regions (Pohjois-Karjala, Etelä-Savo and Pohjois-Savo), where the net out-migration increased substantially from 1951-1955 to $1961-1965$. In one region (Keski-Pohjanmaa) the heavy losses were considerably reduced in the 1960 's, as opposed to the dominant trend. As a whole, urban communes received substantial net in-migration in every economic region, although the regional distribution and trends of the gain were rather heterogeneous. As far as urban communes were concerned, however, the variation in net migration diminished, while it increased in rural communes. Only rural Uusimaa gained by migration, whereas the total loss of all the rual communes rose from 7.2 per 1000 population per annum in $1951-1955$ to 11.4 in 1961-1965.

The number of communes gaining by internal migration was rather stable about 60 urban communes, and around 50 rural communes, most of them in the vicinity of cities. These communes are indicated in Cartogram 3, which also shows that outside the immediate sphere of influence of cities, only five rural 

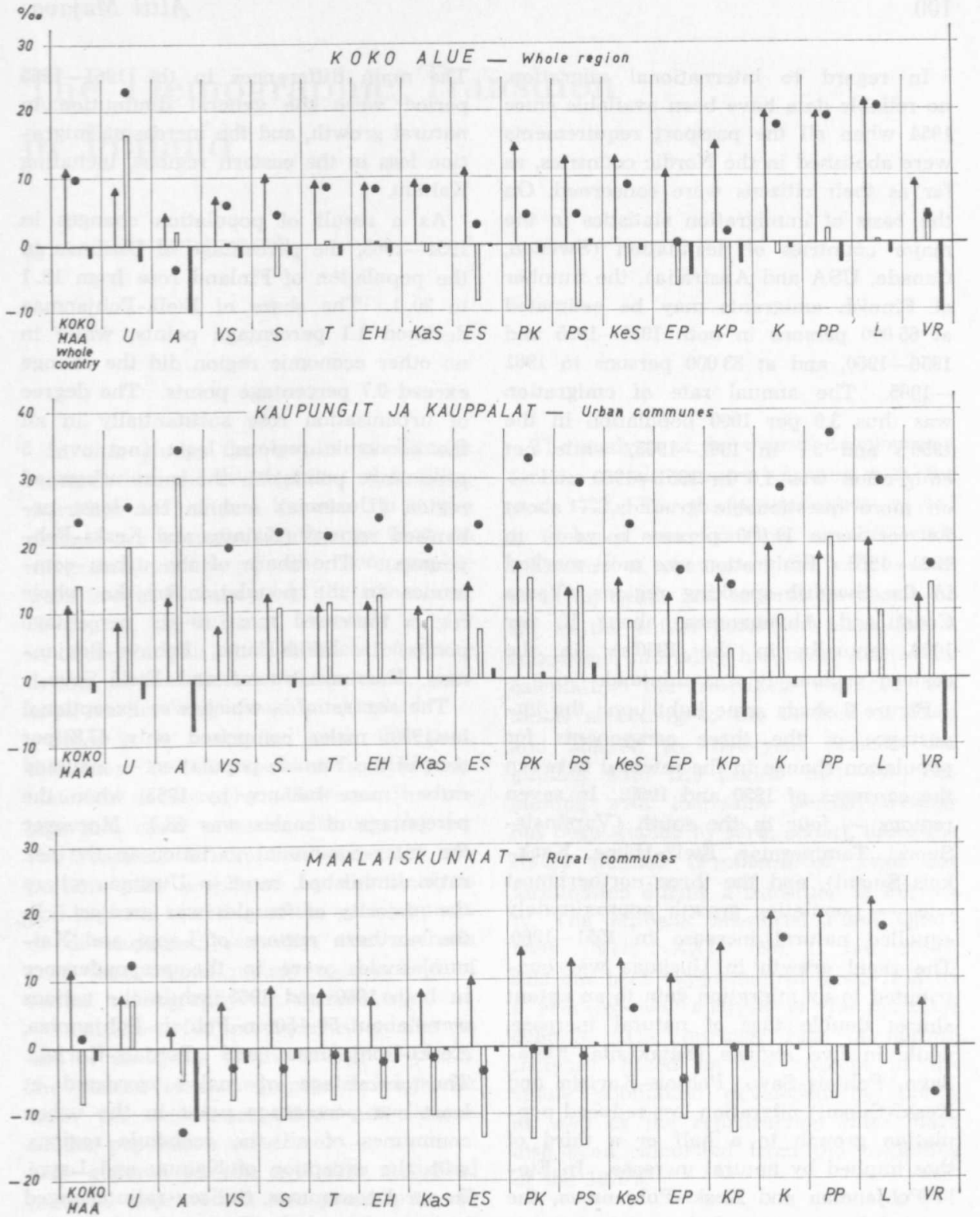

Figure 2. Components of actual population change by economic regions and urban/rural residence, annual averages for 19511960 , per 1000 population.

communes (Harjavalta, Inari, Jämsä, Nurmijärvi and Säkylä) gained by migration in each five-year period. The highest rates of net in-migration were recorded in two communes (Espoo and Helsingin mlk) bordering upon Helsinki. 
In regard to international migration, no reliable data have been available since 1954 when all the passport requirements were abolished in the Nordic countries, as far as their citizens were concerned. On the basis of immigration statistics in the major countries of destination (Sweden, Canada, USA and Australia), the number of Finnish emigrants may be estimated at 65000 persons in both 1951-1955 and 1956-1960, and at 83000 persons in 1961 -1965. The annual rate of emigration was thus 3.0 per 1000 population in the 1950 's and 3.7 in 1961-1965, while net emigration was 1.6 in $1951-1960$ and on more questionable grounds - about 2.4 (or some 11000 persons a year) in 1961-1965. Emigration was most marked in the Swedish-speaking regions (Vaasa Coast and Ahvenanmaa, about 10 per 1000 annually in the 1950 's); in the eastern regions it was minimal.

Figure 2 sheds some light upon the importance of the three components for population change in the interval between the censuses of 1950 and 1960. In seven regions - four in the south (VarsinaisSuomi, Tammermaa, Etelä-Häme, Kaakkois-Suomi), and the three northernmost ones - population growth approximately equalled natural increase in 1951-1960. The rapid growth in Uusimaa was contributed to by migration gain to an extent almost double that of natural increase, while in five regions (Satakunta, EteläSavo, Pohjois-Savo, Pohjois-Karjala and Keski-Suomi) migration loss reduced population growth to a half or a third of that implied by natural increase. In Etelä-Pohjanmaa and Keski-Pohjanmaa, the natural increase was balanced by migration factors, so that the population change was small. On the Vaasa coast, and in Ahvenanmaa, emigration played the leading role in population change. The rapid population growth in urban communes resulted from natural increase and migration gain; in several regions - as in the whole country - their contributions were about equal. In rural communes, natural increase and migration loss more or less balanced each other in most regions, with Uusimaa as a notable exception.
The main differences in the 1961-1965 period were the general diminution in natural growth, and the increasing migration loss in the eastern regions, including Kainuu.

As a result of population changes in 1951-1965, the percentage of Uusimaa in the population of Finland rose from 16.1 to 20.1. The share of Etelä-Pohjanmaa declined 1.1 percentage points, while in no other economic region did the change exceed 0.7 percentage points. The degree of urbanisation rose substantially in all the economic regions, least (not over 5 percentage points) in the most urbanised region (Uusimaa) and in the least urbanised regions (Kainuu and Keski-Pohjanmaa). The share of the urban communes in the population of the whole region increased most (9-11 percentage points) in Etelä-Häme, Pohjois-Pohjanmaa, Varsinais-Suomi and Etelä-Savo.

The sex ratio - which was exceptional in 1950: males comprised only 47.8 per cent of the Finnish population - assumed rather more balance by 1965 , when the percentage of males was 48.3. Moreover the inter-communal variation in the sex ratio diminished, most in Uusimaa where the majority of females was greatest. In the northern regions of Lappi and Kainuu, males were in the preponderance in both 1950 and 1965 , while the rations were about $50-50$ in Pohjois-Pohjanmaa, Keski-Pohjanmaa and Pohjois-Karjala. The percentage of males increased at least one percentage point in the urban communes of all the economic regions, with the exception of Kainuu and Lappi In rural communes, the sex ratio changed little on the whole. By reason of the declining birth rate, the percentage of children under 15 diminished in all the economic regions, whereas proportion of old people (over 65) increased. Furthermore the proportion of persons of working age (15-64 years) increased in all the regions, except Uusimaa, by at least one percentage point. The changes in the age structure were as a rule considerably smaller in urban communes than in rural communes, although Uusimaa was again an exception. 